\title{
Clio
}

Women, Gender, History

$38 \mid 2013$

Working Women, Working Men

\section{The Worst of Adventures: the Knight Yvain and the silk weavers (late twelfth century)}

La Pire des Aventures: le chevalier Yvain et les tisseuses de soie

\section{Sophie Cassagnes-Brouquet}

Translator. Michèle R. Greer

\section{OpenEdition}

\section{Journals}

\section{Electronic version}

URL: http://journals.openedition.org/cliowgh/313

DOI: $10.4000 /$ cliowgh.313

ISSN: 2554-3822

Publisher

Belin

\section{Electronic reference}

Sophie Cassagnes-Brouquet, «The Worst of Adventures: the Knight Yvain and the silk weavers (late twelfth century) », Clio [Online], 38 | 2013, Online since 15 September 2014, connection on 19 April 2019. URL : http://journals.openedition.org/cliowgh/313 ; DOI : 10.4000/cliowgh.313 


\section{The Worst of Adventures: the Knight Yvain and the silk weavers (late twelfth century)}

Sophie CASSAGNES-BROUQUET

In the twelfth century, the word ovrer and then ovrier ("worker") appeared in the langue d'oil as a derivation of the Latin word operarius or one who works with his hands. Yvain, the Knight of the Lion [Yvain, le chevalier au lion], a romance written by Chrétien de Troyes between 1176 and 1181, provides one of the first descriptions of employed female workers in the Middle Ages. Here, the brutal confrontation between the valiant knight and the reality of female labour gives rise to one of the most striking episodes of medieval literature. It testifies to a new reality - that of work, money and working conditions - at the heart of Arthurian fantasy.

Yvain, the Knight of the Lion is part of the Matter of Britain, a body of literature glorifying the exploits of the Knights of the Round Table. ${ }^{1}$ This novel in octosyllabic verse draws its inspiration from the Matter of Wales, such as the tale of Owain or the Lady of the Fountain. ${ }^{2}$ The story begins in King Arthur's court with Calogrenant, a Round Table Knight, telling how he discovered a magnificent fountain in the Brocéliande forest only to be attacked by a black knight who unseated him and stole his horse. Deciding to avenge him, his cousin Yvain enters the forest and discovers a castle. He falls in love with and marries the Lady Laudine, who resides there. Quickly, the valiant Yvain grows nostalgic and wants to leave in search of adventure. His wife accepts, provided that he returns within a year. During his quest, Yvain forgets his

\footnotetext{
1 Frappier 1969.
}

2 Lambert 1993. 
promise and Laudine lets him know that she never wants to see him again. Mad with grief, Yvain loses his mind, goes into the forest and returns to the wild. Nursed by a damsel, he comes to his senses and sets out again. Along the way, he sees a lion fighting a dragon, comes to the lion's aid, and together they conquer the diabolical animal. From that moment on, the lion follows him everywhere and together they accomplish multiple feats of arms. At this point, a damsel asks him to help her recover her inheritance. They come to the castle of Pesme Aventure, the so-called Worst Adventure because all the knights who have tried to overcome the two demons ruling over it have failed. With the help of his lion, Yvain is victorious, returns to King Arthur's court, and is forgiven by his wife Laudine.

\section{The Pesme Adventure}

The Knight of the Lion's encounter with the world of labour takes place in the cursed castle of Pesme Aventure. Upon Yvain's arrival, the inhabitants, defying all the duties of hospitality, tell him he is not welcome and warn him that shame and humiliation await him there. ${ }^{3} \mathrm{~A}$ lady comes to explain that it is the custom to prohibit foreign knights from receiving accommodation there. Outraged by this lack of courtesy, Yvain insists, so she declines any responsibility as the porter opens the door.

The porter, after addressing him with this very ungracious welcome, hurried upstairs. But my lord Yvain, without making reply, passed straight on, and found a new and lofty hall; in front of it there was a yard enclosed with large, round, pointed stakes, and seated inside the stakes he saw as many as three hundred maidens, working at different kinds of embroidery. Each one was sewing with golden thread and silk, as best she could. But such was their poverty, that many of them wore no girdle, and looked slovenly, because so poor; and their garments were torn about their breasts and at the elbows, and their shifts were soiled about their necks. Their necks were thin, and their faces pale with hunger and privation. They see him, as he looks at them, and they weep, and are unable for some time to do anything or to raise their eyes from the ground, so bowed down they are with woe... ${ }^{4}$

\footnotetext{
3 Poirion 1994: 337-503, 462-463.

4 Ca 5187-5213 [463-464 in the Comfort edition].
} 
Yvain wants to turn back, but the porter dissuades him. When the Knight of the Lion asks the porter who these poor girls are, he refuses to answer, so Yvain goes back to see them. They tell him that they are from the Isle of Damsels, the kingdom of Celtic fairies such as Morgan le Fay. ${ }^{5}$ Its prince, wishing to travel the world in search of adventure, came to this cursed place resided in by two demons. These demons, born of a woman and a netun, ${ }^{6}$ beat him and forced him to pay an annual tribute of thirty maidens for as long as the two manfes [evil spirits] should live. This terrible arrangement having gone on for ten years, there are now three hundred maidens held captive and condemned to work day and night.

We shall spend our days weaving cloths of silk, without ever being better clad. We shall always be poor and naked, and shall always suffer from hunger and thirst, for we shall never be able to earn enough to procure for ourselves any better food. Our bread supply is very scarce - a little in the morning and less at night, for none of us can gain by her handiwork more than four pence [...] for her daily bread. And with this we cannot provide ourselves with sufficient food and clothes. For though there is not one of us who does not [do enough work to] earn as much as twenty sous a week, yet we cannot live without hardship. Now you must know that there is not a single one of us who does not [perform] twenty sous worth of work or more, and with such a sum even a duke would be considered rich. So while we are reduced to such poverty, he, for whom we work, is rich with the product of our toil. We sit up many nights, as well as every day, to earn the more, for they threaten to do us injury, when we seek some rest, so we do not dare to rest ourselves. But why should I tell you more? We are so shamefully treated and insulted that I cannot tell you the fifth part of it all. ${ }^{7}$

After these purely material considerations, the chivalric narrative quickly takes over, as the young maidens speak of the knights who have sought to release them but failed, and plead with Yvain to deliver them, Yvain goes deeper into the castle, carrying all their hopes. Inside, he discovers its sumptuous rooms where the noble family lives in luxury, especially their only - and very coddled daughter who is as richly dressed as the weavers are miserable.

5 Frappier 1969: 11.

6 The term "netun", from the Latin neptunius, means an evil villain. The manuscripts refer to "luiton" and then "luton". Woledge 1988: 90.

7 Ca 5300-5326 [446-447 in the Comfort edition] 


\section{Chivalry and new urban realities}

This episode of the Three Hundred Damsels is one of the best known and most controversial of twelfth-century chivalric literature. This irruption of "social realism" into the world of Arthurian magic has been written about extensively. Many commentators have seen it as a reflection of historical reality, while others have spoken out against the historical implausibility of this workshop of three hundred women weaving silk. ${ }^{8}$ As Jean Frappier has pointed out, this was the first time Chrétien de Troyes looked beyond an aristocratic setting. ${ }^{9}$ The very precise description given of the women weavers' condition, miserable and burdened with work, is actually not very far from those laid out in the earliest documents describing such activity in the following century. However, it is also not difficult to see its inconsistencies: first, the size of the workshop - three hundred women - is an absurd figure for the emerging textile industry; second, the occupation of silk weaving really only developed in the Italian city of Lucca, which held a quasi-monopoly in the West; and finally, the workshop's location within a castle instead of in an industrial city. ${ }^{10}$ While these objections are quite appropriate, it is also certain that Chrétien de Troyes could not have invented such accurate details about the workers' wages. He was inspired by some kind of reality, albeit exaggerated (number of workers) and embellished (silk and gold thread instead of wool or linen; an enchanted castle instead of an urban workshop). In spite of these reservations, it is not impossible to see in the terrible treatment imposed on these three hundred weavers - suffering from hunger, half-naked, humiliated and exploited - some echo of the economic growth and development of the textile crafts witnessed in Champagne, a region famous for its fairs, the economic centre of western Europe. ${ }^{11}$

But perhaps what is the most important here is the appearance of money and waged labour as opposed to the idleness and wanderings

8 Lepage 1991: 160-161.

9 Frappier 1969: 122.

10 Herlihy 1990: 80. He notes this passage of Yvain to liken it to the gynaecea in castles or the textile workshops in women's convents.

11 Baumgartner 2003: 109; Jonin 1964: 52-53; Contamine et al. 2001: 184 and 249-251. 
of the knight of Arthurian romance. Realism is not only present, but brutally so, as the weavers' complaints are about money and cold, hard cash. ${ }^{12}$ Their "spokeswoman" complains about earning only four deniers a day, just enough not to starve, while their work brings their tormentors at least 20 sous, i.e. one livre. ${ }^{13}$ Their work therefore brings the demons 240 deniers -60 times more than they make! ${ }^{14}$ Here again, Chrétien de Troyes seems to have painted a darker picture. While there are not many accounting records available for the period, the fourteenth century gives us more information, with sources citing, for example, a woman mattress-maker earning a salary of 6 deniers per day in Artois in 1314. ${ }^{15}$

In any case, this is no example of "working-class protest" as Jean Frappier thought. ${ }^{16}$ Chrétien de Troyes's women weavers do not wish to earn more and work less. They simply want the knight to liberate them from this unworthy task, and not to have to work at all, by going back to the Isle of Damsels. ${ }^{17}$ Compared to Yvain - himself and his time being his own - these women are condemned to work all day inside a locked enclosure from which they cannot escape. Yvain and the lion's victory over the two demons allows them to return to the world of Arthurian magic from which they had been brutally snatched. ${ }^{18}$ The Arthurian Utopia thereby comes into its own again over the terrible "new world" of the cities. ${ }^{19}$

Translated by Michèle R. GREER

12 Frappier 1969: 127.

13 In the medieval monetary system: 1 sou $=12$ deniers, 1 livre $=20$ sous, 1 livre $=$ 240 deniers. The livre is a unit of account; the money in circulation in Champagne during Chrétien de Troyes's lifetime was the Provins denier.

14 Lepage 1991: 164.

15 Dancoisne 1847: 82; Jonin 1964: 52.

16 Frappier 1969: 128.

17 Lepage 1969: 165.

18 Baumgartner 2003: 110.

19 Köhler 1974. 


\section{Bibliography}

Baumgartner, Emmanuele. 2003. Romans de la Table Ronde de Chrétien de Troyes. Paris: Gallimard.

Contamine, Philippe, Marc Bompaire, Stéphane LebecQ, and Jean-Luc Sarrazin. 2001. L'Économie médiévale. Paris: Armand Colin.

Chrétien de Troyes. 2009. Four Arthurian Romances. Translated by W.W. Comfort. E-book: The Floating Press [Also available via Project Gutenberg].

Dancoisne, M. 1847. Recherches historiques sur Hénin-Liétard. Douai.

FRAPPIER, Jean. 1969. Étude sur Yvain ou le chevalier au lion de Chrétien de Troyes. Paris: SEDES.

Herlihy, David. 1990. Women and Work in Medieval Europe. Philadelphia: Temple University Press.

JonIN, Pierre. 1964. Aspects de la vie sociale au XII siècle dans Yvain. L'information littéraire 2: 47-54.

KÖHLER, Erich. 1974. L'Aventure chevaleresque. Idéal et réalité dans le roman courtois. Paris: Gallimard.

LAMBert, Pierre-Yves (ed.). 1993. Les Quatre branches du Mabinogi et autres contes gallois du Moyen Age. Paris: Gallimard.

LePage, Yvan G. 1991. Encore les trois cents pucelles (Chrétien de Troyes, Yvain, v. 5298-5324). Cabiers de civilisation médiévale 134: 159-166.

Woledge, Brian. 1988. Commentaires sur Yvain (Le Chevalier au lion) de Chrétien de Troyes. Geneva: Droz. 